\title{
Persepsi Stakeholders tentang Kinerja Fungsi Sistem Penelitian Kesehatan Nasional
}

\author{
Anni Yulianti*
}

\begin{abstract}
Abstrak
Analisis kinerja fungsi sistem penelitian kesehatan nasional (SPKN) diperlukan untuk identifikasi penguatan dan peningkatan sistem yang mendukung pencapaian pemerataan kesehatan. Penelitian ini bertujuan mengukur skor kinerja fungsi utama SPKN yang meliputi pengelola, pendanaan, mengumpulkan dan memelihara sumber, produksi dan penggunaan riset berdasarkan pendapat stakeholders (peneliti, pembuat kebijakan, dan pengguna). Sumber data yang digunakan adalah pilot study WHO di Jakarta dan Makassar WHO dengan ukuran sampel 278 responden. Analisis dilakukan terhadap skor rata-rata 6 dimensi pendapat meliputi lingkungan; pandangan sistem, pembuatan, penggunaan, akses literur ilmiah dan media. Metoda analsis meliputi analisis kuantitatif univariat dan cross tabulasi tanpa uji statistik dan analisis kualitatif terhadap pertanyaan terbuka. Hasil studi memperlihatkan distribusi responden meliputi peneliti (62.2\%), pembuat kebijakan (21.6\%) dan pengguna (16.2\%). Secara keseluruhan, kinerja fungsi sistem litkes dinilai belum baik oleh $54,7 \%$ responden. Kinerja baik ditemukan pada fungsi pengelola dan penghasil riset. Sebaliknya kinerja tidak baik pada fungsi pengumpul dan pemelihara sumber daya, menggunakan riset, akses literatur ilmiah dan akses media. Analisis kualitatif memperlihatkan lima area yang berkontribusi penting pada penguatan lingkungan penelitian di indonesia meliputi pendanaan, fasilitas, gaji, kerjasama, dan komunikasi. Komponen yang dinyatakan penting pada penguatan sistem litkes adalah visi, sumber data manusia, pendanaan, etik litkes dan alokasi. Prioritas utama SPKN adalah masalah kesehatan masa depan dan masalah kesehatan yang persisten (bertahan lama). Disimpulkan bahwa SPKN belum berfungsi optimal. Peningkatan dapat dilakukan dengan revisi dan reorientasi prioritas SPKN antar stakeholders, peningkatan alokasi dana, optimalisasi peran dan fungsi jaringan litbangkes, serta peningkatan fungsi stewardship badan litbangkes dalam kapasitas kepemimpinan ilmiah yang baik .
\end{abstract}

Kata kunci : Penilaian kinerja, sistem riset kesehatan nasional

\begin{abstract}
National health research system (NHRS) performance assessment will be very important to strengthen the capability of NHRS in order to improve the advancement of knowledge and health equity. The objective of this study is to measure the three functions performance of stewardship, creating and sustaining resources and producing and utilizing of health research based on the perceptions of NHRS stakeholders (researchers, policy makers and users). This study used secondary data WHO pilot study which was carried out in Jakarta and Makassar, in 2003-2004. The study design used is cross sectional with quantitative and qualitative data analysis for 278 respondents of NHRS individual survey. The respondents consist of NHRS stakeholders such as researchers (62.2\%), policy makers (21.6\%) and research users (16.2\%). Overall performance of NHRS functions has been perceived as not well performed by $50.4 \%$ respondents. Good performances only on stewardship and producing research have been perceived by respondents. In the other hand, the performance of creating and sustaining resources, research utilization, access to scientific literatures and to media have been perceived unsatisfactorily by the respondents. Important contribution areas in improvement and strengthening the NHRS in Indonesia are: networking, facility, budget, collaboration and communication. While important contribution components in Indonesia are vision, human resources, ethics, budget and allocation. The main research priorities were identified as future health problem and persistent health problem in all respondent's groups. In summary, NHRS were not yet in optimum well functions., to strengthen the system: pledged to increase budget allocation and improve budget accountability; activating the national and local net working of health research and development, improvement of stewardship function of NHRS in its capacity as 'good scientific leadership'
\end{abstract}

Key words : Health research system, performance assessment.

* Staf Sekretariat Komisi Etik Penelitian Kesehatan \& IImiah Badan Penelitian dan Pengembangan Kesehatan, Depkes RI 
Setiap tahun lebih dari US \$ 70 milyar digunakan untuk penelitian dan pengembangan kesehatan (litbangkes), baik oleh sektor umum (pemerintah) maupun swasta. Namun, hanya sekitar 10\% hasil penelitian tersebut yang digunakan untuk memecahkan 90\% masalah kesehatan dunia. Hal ini sering disebut sebagai kesenjangan 10/90 atau 10/90 gap. ${ }^{1}$ Di beberapa negara, sistem penelitian kesehatan belum mampu berkontribusi besar terhadap peningkatan derajat kesehatan masyarakat. Diperlukan strategi global untuk memperkuat sistem kesehatan dengan pendekatan iptek kesehatan, dengan cara membangun dan meningkatkan kinerja fungsi sistem litkes sebagai otak sistem kesehatan. ${ }^{2}$

Sejak tahun 1999, WHO telah mengembangkan konsep health research sistem atau sistem penelitian kesehatan. Menurut WHO sistem litkes adalah kumpulan orang, institusi, dan aktifitas dengan tujuan utama mendapatkan pengetahuan berkualitas tinggi untuk digunakan sebagai promosi, penyimpanan dan atau mempertahankan status kesehatan masyarakat, termasuk mekanisme yang diambil untuk mendorong pemanfaatan penelitian. ${ }^{3}$ Dalam sistem kesehatan nasional 2004 di Indonesia, penelitian dan pengembangan kesehatan merupakan salah satu unsur utama pada sub sistem manajemen kesehatan guna mendukung pencapaian tujuan normatif pembangunan kesehatan, yang meliputi derajat kesehatan (goodness in health), efisiensi pelayanan kesehatan (efficiency), keadilan dalam pelayanan dan pembiayaan (fairness), serta kualitas pelayanan kesehatan (quality). ${ }^{4}$

Menurut WHO, ada 4 fungsi utama yang berperan sebagai indikator kinerja sistem penelitian kesehatan. Fungsi yang pertama adalah stewardship yang bermakna memberikan arahan leadership untuk promosi dan mengembangkan visi strategis sistem penelitian kesehatan, mengembangkan dan memantau pelaksanaan standar etik penelitian kesehatan dan melakukan pemantauan dan evaluasi terhadap kinerja sistem kesehatan secara keseluruhan. Kedua, pembiayaan (financing) yaitu menjamin alokasi anggaran dan akuntabilitas penggunaannya. Fungsi berikutnya adalah creating and sustaining resources, yang berarti membangun kapasitas (capacity building) baik fisik dan non fisik penyelenggaran dan pemanfaatan penelitian kesehatan. Sedangkan, producing and using research merupakan fungsi terakhir yang berarti menghasilkan penelitian yang bermutu untuk mendukung kemajuan ilmu pengetahuan dan teknologi kesehatan dalam rangka meningkatkan pemerataan dan status kesehatan individu dan masyarakat dan pengembangan program dan kebijakan kesehatan.

Diskusi yang berkembang selanjutnya adalah cara mengukur kinerja sistem penelitian kesehatan di suatu negara agar mampu mengidentifikasi kekurangan yang ada dan sekaligus mengembangkan potensi yang dimiliki untuk melakukan percepatan kinerja sistem. Sebagai langkah awal untuk mengukur kinerja sistem penelitian kesehatan na- sional, pada tahun 2003 - 2004, WHO melaksanakan pilot phase study di 17 negara. ${ }^{5}$ Di Indonesia survey ini dilaksanakan oleh Badan Litbangkes, Depkes RI yang karena keterbatasan dana dan aktifitas penelitian menurut kawasan maka dipilih Jakarta (representasi Kawasan Barat Indonesia) dan Makassar (representasi Kawasan Tengah dan Timur Indonesia) sebagai daerah pilot study. ${ }^{6}$ Indikator pengukuran kinerja dikembangkan berdasarkan kerangka fungsi sistem penelitian kesehatan menurut WHO. Survey ini menggunakan instrumen/kuesioner WHO. Dari 4 jenis kegiatan pilot study yang meliputi : (1) survey individu (peneliti, pemberi dana, pengguna hasil penelitian); (2) survey institusi ; (3) kajian media cetak (surat kabar); (4) focus group discussion (FGD); Indonesia hanya melaksanakan 2 survey yaitu survey individu dan survey media. ${ }^{5}$

Desain yang dikembangkan WHO untuk analisis integral sistem penelitian kesehatan pada pilot study health reserach system analysis (HRSA) adalah yang pertama kali dilaksanakan di Indonesia. Pilot studi tersebut telah selesai dilaksanakan di Indonesia pada awal tahun 2004 (dari pengumpulan data sampai entry), tetapi sampai saat ini data Indonesia belum dianalisis lanjut. Walaupun merupakan pilot studi, tetapi data yang telah diperoleh dapat dimanfaatkan untuk mendapatkan gambaran awal mengenai kinerja sistem penelitian kesehatan nasional. ${ }^{5}$ Hasil awal tersebut selanjutnya dapat menjadi masukan lebih lanjut dalam mengembangkan metode evaluasi kinerja fungsi sistem penelitian kesehatan secara keseluruhan yang lebih sesuai dengan situasi dan kondisi di Indonesia.

Penulis merasa tertarik untuk memanfaatkan data tersebut sebagai topik penelitian, khususnya data survey individu. Survey individu ini lebih variatif respondennya baik dari latar belakang keilmuan, institusi maupun pengalamannya dan menggali penilaian individu mengenai sistem penelitian kesehatan nasional. Selain itu survey ini merupakan survey langsung kepda para stakeholders penelitian kesehatan atau sifatnya population based. Survey-survey yang ada tentang sistem penelitian kesehatan biasanya menggunakan institusi sebagai responden atau informan. Penelitian ini bertujuan untuk menganalisa kinerja fungsi sistem litbangkes menurut 3 fungsi sistem yaitu creating and sustaining resources, stewardship, dan producing and using research berdasarkan pendapat stakeholdesr (peneliti, pembuat kebijakan, dan pengguna hasil penelitian kesehatan) serta mengidentifikasi area dan komponen dalam sistem penelitian kesehatan untuk prioritas perbaikan dan peningkatan di Indonesia.

\section{Metode}

Penelitian ini merupakan studi deskriptif analitik (kuantitatif dan kualitatif) dengan desain studi cross sectional. Penelitian ini akan menggunakan data sekunder dari pilot studi NHRS survey individu.

Analisis kuantitatif dilakukan dengan distribusi frekuen- 
si (univariat) karakteristik responden yang meliputi kelompok, jenis kelamin, umur, institusi, jabatan, pengalaman bekerja, tingkat pendidikan, kemampuan bahasa Inggris, penghasilan dan pelatihan. Untuk melengkapi gambaran analisis, beberapa tabulasi silang (bivariat) dibuat tanpa uji statistik. Sebelum melakukan penghitungan skor kinerja, dilakukan analisis faktor eksplanatori untuk modul 2000 dan 3000 yaitu hanya pada penilaian kinerja fungsi sistem creating and sustaining resources dan stewardship. Analisis faktor dilakukan untuk memudahkan pengelompokan jawaban responden kedalam fungsi sistem penelitian kesehatan sesuai kerangka konsep yang dikembangkan. Selain itu, analisis faktor dilakukan untuk melihat hubungan dari berbagai variabel yang diidentifikasikan faktor dengan melihat variasi atau kovarian di antara pengukuran.

Penilaian skor kinerja fungsi sistem dibedakan atas penilaian menurut berbagai dimensi dan juga berdasarkan hasil analisis faktor. Pengukuran kinerja dilakukan dengan menghitung rata-rata skor menurut persepsi/pendapat dan pengalaman real responden pada 6 dimensi yaitu : lingkungan penelitian kesehatan, pandangan sistem pada penelitian kesehatan, pembuatan litkes, penggunaan litkes, akses literur ilmiah dan akses media. Dimensi penilaian tersebut akan direpresentasikan menurut tiga jenis fungsi sistem penelitian kesehatan versi WHO yaitu:

1. Creating and sustaining resources yaitu pada modul 2000 tentang lingkungan penelitian kesehatan

2. Stewardship yaitu pada modul 3000 tentang pandangan sistem pada penelitian kesehatan

3. Creating and using research yaitu pada modul 4000 tentang pembuatan dan penggunaan penelitian kesehatan

Dari kuesioner ada 2 modul yaitu modul 2000 dan modul 3000 yang merupakan pendapat responden dengan rentang skor penilaian dari 1 (sangat baik) sampai 5 (sangat buruk) dan nilai tengah 3 (cukup). Sedangkan khusus untuk modul 4000 mengenai pembuatan dan penggunaan riset kesehatan, penilaian kinerja didasarkan atas aktifitas nyata responden dalam kegiatan penelitian kesehatan. Ada 2 macam rentang skala penilaian untuk modul ini yaitu $1-2$, karena hanya berisi jawaban ya atau tidak, dan rentang skala 1 - 5; yaitu (1) tidak pernah; (2) 3-4 kali; (3) setiap bulan; (4) setiap minggu; (5) setiap hari.

Bagi jawaban yang kosong, maka skor reponden atas pernyataan tersebut dinilai 0 dan rata-rata skor tetap dihitung menurut jumlah pernyataan. Seluruh skor kinerja merupakan skor rata-rata yang kemudian dikelompokkan menjadi 2 kategori kinerja yaitu: tidak baik jika $\leq$ nilai rata-rata skor dan baik jika > nilai rata-rata.

Selain pemanfaatan data kuantitatif, penelitian ini akan dilengkapi dengan analisis kualitatif terhadap pertanyaan terbuka pada kuesioner. Disamping itu, kajian literatur dari berbagai sumber kepustakaan yang terkait dengan topik penelitian akan dilakukan untuk memperkaya hasil penelitian.

Pemanfaatan data sekunder menyebabkan adanya keterbatasan peneliti untuk mengontrol validitas dan kelengkapan data. Jumlah sampel akhir yang dianalisis adalah 278 dari 325 responden yang diwawancarai. Karena merupakan survey yang pertama kali diadakan, maka ditemukan kesulitan mencari data pembanding untuk Indonesia.

\section{Hasil}

\section{Pengelompokkan Variabel Pernyataan}

Pengelompokan variabel pernyataan dilakukan dengan menggunakan metode analisis faktor. Analisis faktor dilakukan untuk 2 modul, yaitu modul 2000 tentang lingkungan penelitian dan modul 3000 tentang pandangan sistem pada penelitian kesehatan.

Analisis faktor pada modul 2000 menghasilkan 4 faktor yang terbentuk dari 16 item pernyataan. 4 faktor tersebut adalah (1) dukungan area-area lingkungan untuk kegiatan penelitian kesehatan - 8 pernyataan; (2) lingkungan penelitian kesehatan nasional secara umum -3 pernyataan; (3) dana dan fasilitas - 2 pernyataan; dan (4) keadaan penelitian kesehatan di institusi secara umum - 1 pernyataan.

Hasil validasi menunjukkan faktor yang terbentuk sudah valid. Jika melihat redaksi pernyataan yang ditanyakan kepada responden sulit untuk mengkategorikan kembali keempat faktor yang terbentuk dalam salah satu fungsi 'creating' atau 'sustaining' karena fungsi tersebut sangat terkait erat dan beberapa pernyataan menggabungkan keduanya. Hal ini didukung dengan hasil analisis faktor yang mengelompokkan variabel/pernyataannya tidak dapat dikelompokkan ke dalam fungsi creating' atau 'sustaining'.

Sedangkan hasil analisis faktor untuk modul 3000 tentang pandangan sistem pada penelitian kesehatan adalah 2 (dua) faktor dari 6 item pernyataan; yaitu faktor (1) komponen-komponen manajemen sistem penelitian kesehatan nasional - 5 pernyataan; dan (2) fungsi sistem penelitian kesehatan nasional secara umum - 1 pernyataan.

Sama seperti pada modul 2000, uji validasi yang dilakukan untuk modul 3000 ini menunjukkan hasil yang baik. Dari hasil validasi yang dilakukan didapatkan bahwa faktor yang terbentuk kurang valid karena jumlah faktor yang terbentuk tidak sama setelah kasus dipecah manjadi 2 bagian dan dilakukan analisis faktor untuk masing-masing bagian tersebut masing-masing bagian mengelompok pada 1 faktor.

Secara umum sebenarnya hasil analisis faktor tidak memunculkan kelompok dimensi penilaian baru di luar lingkungan penelitian atau pandangan sistem pada penelitian kesehatan. Dengan demikin selanjutnya penilaian kinerja dapat dilakukan menurut kedua dimensi tersebut atau tidak perlu dipisahkan menurut faktor yang terbentuk.

\section{Karakteristik Responden}

Kelompok responden dalam penelitian ini atau yang 
disebut sebagai stakeholders dalam sistem penelitian kesehatan dibedakan menjadi 3 kelompok yaitu peneliti, pembuat kebijakan, dan pengguna hasil litkes. Pada penelitian ini $62,2 \%$ responden adalah peneliti atau yang sering disebut sebagai 'produser' utama yang bertanggung jawab menghasilkan penelitian dan terlibat langsung dalam keseluruhan aktifitas penelitian kesehatan. Sedangkan kelompok responden pembuat kebijakan yang juga berperan sebagai pengambil keputusan termasuk dalam hal pendanaan (penyandang dana) sejumlah $21,6 \%$ dan sisanya $(16,2 \%)$ adalah pengguna hasil litkes. Sebanyak $80.9 \%$ responden dari kota Jakarta dan 19,1\% dari kota Makassar.

Aktifitas penelitian kesehatan lebih banyak berpusat di Jakarta, bukan dalam arti sebagai daerah penelitian tetapi karena perannya sebagai sentra pemerintahan. Hal ini tentu akan mempengaruhi percepatan aktivitas penelitian kesehatan dibanding daerah lain di Indonesia, termasuk dalam keterlibatan stakeholders dalam perumusan kebijakan-kebijakan yang menyangkut aktifitas penelitian kesehatan.

Jenis kelamin responden meliputi laki-laki $(59,4 \%)$ dan wanita $(40.6 \%)$. Kondisi ini tidak berbeda dengan Laos yang sebagian besar respondennya adalah laki-laki $(70 \%$ laki-laki). Hal ini menunjukkan bahwa dari segi gender keterlibatan wanita dalam bidang penelitian kesehatan cukup banyak. Lebih detil hasil penelitian juga menunjukkan persentase laki-laki dan perempuan untuk kelompok peneliti hampir berimbang (55,5\% dengan 44,5\%), sedangkan pada kelompok pembuat kebijakan dan pengguna hasil litkes sedikit didominasi laki-laki.

Pertanyaan mengenai tahun kelahiran responden dijawab oleh 272 orang (98\%), responden terbanyak berumur 45 - 54 tahun $(47,8 \%)$, yang selanjutnya diikuti oleh kelompok umur $35-44$ tahun (32\%), kelompok umur di atas 55 tahun $(12,5 \%)$, dan sisanya kelompok umur $>60 \%$ yang merupakan pegawai senior yang berada pada periode 'puncak karir'.

Sebagian besar responden bekerja di institusi pemerintah $(86 \%)$, sedangkan sisanya $14 \%$ dari institusi non pemerintah. Keterlibatan sektor swasta dalam sistem penelitian kesehatan masih kecil yaitu hanya sekitar 7.2\%. Hasil penelitian yang sama di Laos menyebutkan bahwa 97\% stakeholders adalah dari institusi pemerintah dan sektor swasta $1,2 \%$. Sedangkan penelitian lain adalah Amerika (2001) $85 \%$ berasal dari institusi pemerintah. Temuan ini hampir sama dengan survei alur sumber daya penelitian kesehatan, Badan Litbangkes, Depkes RI tahun 2003, institusi yang paling banyak melakukan ataupun sekaligus membiayai penelitian adalah pemerintah $(75 \%)$. Kontribusi sektor swasta dilaporkan masih kecil sekali $(4,5 \%)$. Hasil ini menunjukan dominasi sektor pemerintah dalam sistem penelitian kesehatan. Institusi publik atau pemerintah tidak hanya berperan sebagai pembuat kebijakan termasuk pembiayaan penelitian, atau sebagai pengguna hasil penelitian untuk perencanaan program kesehatan, tetapi juga sekali- gus sebagai pelaksana kegiatan penelitian.

Profesi utama responden adalah peneliti (138) dan akademisi (84) orang. Responden yang bekerja sebagai manajer, baik top manager maupun middle manager di institusinya sebanyak 30,6\% sisanya berprofesi sebagai tenaga kesehatan dan tenaga penunjang penelitian seperti teknisi, tenaga lab, tata usaha, pustakawan, wartawan, dsb. Pekerjaan utama responden tersebut menunjukkan hasil yang sama dengan kelompok responden akademisi (62\%). Di Laos nampaknya penelitian banyak dilakukan oleh kalangan struktural yang meliputi direktur $(11,8 \%)$, wakil direktur $(15,9 \%)$, dekan $(0,6 \%)$, wakil dekan $(1,8 \%)$, kepala bagian $(32,3 \%)$ wakil kepala bagian/kepala sub bagian $(17,1 \%)$ dan staf administrasi $(20,6 \%)$.

Rata-rata responden mempunyai pengalaman bekerja 18 tahun, dengan pengalaman kerja yang terkecil adalah 2 tahun dan yang terbesar 51 tahun. Lebih dari 40\% responden sudah bekerja 16 - 25 tahun dalam menekuni karir profesionalnya. Selain itu $31,74 \%$ responden dengan pengalaman kerja $6-15$ tahun. Hal ini menunjukkan variasi penelitian yang cukup baik, responden yang dipilih sebagian besar adalah pegawai senior, tetapi beberapa pegawai yunior juga dimintakan pendapatnya.

Lebih dari $70 \%$ responden telah menamatkan pendidikan sampai tingkat strata 2 , responden dengan pendidikan pasca sarjana adalah $247(88,9 \%)$, sisanya berpendidikan diploma sampai dengan strata $1(11,2 \%)$. Lebih dari $60 \%$ responden didominasi dengan tingkat pendidikan S2, sedangkan sisanya berbeda pada masing-masing kelompok. Tingkat pendidikan S3 di kelompok peneliti sebanyak $22 \%$, sedangkan di kedua kelompok lainnya masing-masing sebesar 4,7\% (pembuat kebijakan) dan 7\% (pengguna hasil litkes). Pada kedua kelompok ini, tingkat pendidikan S1 lebih besar dibanding S3. Dari 43 orang yang telah mendapatkan S3, 35 orang $(81,4 \%)$ menyatakan sedang atau telah menyelesaikan pendidikan post doctoral dan 31 orang $(88,6 \%)$ di antaranya adalah peneliti. Tingkat pendidikan yang cenderung sama ini mencerminkan kemudahan komunikasi dan promosi antara stakeholders (peneliti, pembuat kebijakan dan pengguna hasil litkes) dan kebijakan kesehatan.

Lebih dari $65 \%$ responden menyatakan memiliki kemampuan membaca, menulis maupun berbicara bahasa Inggris dengan baik. Tingkat ketrampilan tertinggi adalah pada kemampuan 'membaca' (reading) sebaliknya kemampuan yang kurang baik adalah pada berbicara (oral) dan menulis (writing). Advokasi hasil kesehatan biasanya lebih banyak didasarkan pada kemampuan menulis dan berbicara, sehingga perlu diberikan prioritas pada kegiatan peningkatan kemampuan bahasa dalam 2 hal tersebut. Upaya ini sangat penting mengingat bahasa Inggris sebagai bahasa internasional dan besarnya tuntutan globalisasi yang mensyaratkan penelitian kesehatan harus terdiseminasi dengan baik tidak hanya untuk kepentingan lokal, nasional 
tetapi juga di tingkat regional dan internasional. Selain itu beberapa literatur ilmiah berkualitas biasanya disajikan dalam bahasa Inggris.

Pertanyaan mengenai jumlah penghasilan yang diterima hanya dijawab oleh $202(73 \%)$ responden. Rata-rata penghasilan per bulan responden adalah Rp. 2.500.000, dengan rentang yang cukup besar Rp. 1.000.000 - Rp 20.000.000 per bulan. Penghasilan kelompok peneliti cenderung lebih kecil (59,4\% berada di kelompok $\leq 2,5 /$ bulan) dibanding pembuat kebijakan dan pengguna hasil litkes $(69,2 \%$ dan 53,3\% di kelompok 2,6 - 5 juta/bulan). Meskipun demikian, lebih dari $10 \%$ peneliti berpenghasilan cukup baik yaitu diatas 5 juta/bulan, bahkan mencapai 10 juta ke atas, sementara di kelompok pembuat kebijakan dan pengguna hasil litkes hanya $1 \%$. Lebih detil kelompok $10 \%$ tersebut adalah pns dengan masa kerja lebih dari 20 tahun. Selain penghasilan, reponden juga menyatakan mendapatkan tunjangan (tunjangan bisa lebih dari satu macam) yang sebagian besar berupa cuti, kesehatan dan pensiun.

Sebanyak 92,1\% responden sudah pernah mendapatkan pelatihan dasar di penelitian kesehatan, sedangkan pelatihan penunjang sudah pernah diikuti oleh $80,6 \%$ responden. Pada seluruh kelompok responden, keikutsertaan dalam pelatihan tersebut diatas $50 \%$ baik pada pelatihan dasar maupun penunjang. Jenis pelatihan yang paling banyak diikuti oleh responden adalah mengenai metodologi penelitian, penulisan ilmiah, evaluasi hasil penelitian dan komputer. Sedangkan pelatihan mengenai etika penelitian kesehatan adalah jenis yang prioritas untuk diberikan. Pelatihan lainnya yang juga penting adalah pelatihan mengenai manajemen penelitian dan metode penyebarluasan hasil penelitian yang efektif. Sedangkan untuk jenis pelatihan penunjang lainnya dapat diadakan sesuai kebutuhan dan kemampuan institusi, serta jenisnya dapat lebih beragam. Sayangnya lebih lanjut penelitian ini tidak mengungkapkan bagaimana proses perencanaan dan pembinaan serta pemberdayaan pasca pelatihan diberikan.

\section{Penilaian Kinerja Fungsi}

\subsection{Fungsi Sistem Creating and Sustaining Resources}

Penilaian dimensi ini mencakup penilaian secara umum lingkungan penelitian kesehatan di Indonesia, di institusi, dan dukungan 10 area yang membentuk lingkungan penelitian yang kondusif untuk kegiatan penelitian kesehatan di tingkat nasional. Area-area tersebut mencakup: (1) jangkauan dan wawasan jaringan kerja; (2) transparansi proses pendanaan; (3) kualitas ruang kerja dan fasilitas penelitian kesehatan; (4) kolaborasi dengan peneliti lainnya atau pengguna hasil litkes; (5) kesempatan untuk menampilkan, mendiskusikan dan mempublikasi penelitian kesehatan; (6) relevansi dari aktifitas penelitian kesehatan dengan masalah kesehatan dan sistem kesehatan; (7) bayaran: gaji dan tunjangan; (8) pengembangan karir peneliti; (9) pelatihan; (10) akses memperoleh dan mem- bagi informasi. Hasil perhitungan skor kinerja pada dimensi ini disajikan pada tabel 1.

Tabel 1. Kinerja Dimensi Lingkungan Penelitian Menurut Kelompok Responden

\begin{tabular}{llllllll}
\hline \multirow{2}{*}{$\begin{array}{l}\text { Kelompok } \\
\text { Responden }\end{array}$} & \multicolumn{3}{c}{ Kategori kinerja } & & \multicolumn{2}{c}{ Total } \\
\cline { 2 - 6 } & \multicolumn{2}{c}{ Tidak baik } & \multicolumn{2}{c}{ Baik } & \multicolumn{2}{c}{ N } & $\%$ \\
\hline Peneliti & N & $\%$ & N & $\%$ & & \\
Pembuat kebijakan & 94 & 54.3 & 79 & 45.7 & 173 & 100 \\
Pengguna hasil litkes & 27 & 45 & 33 & 55 & 60 & 100 \\
& 23 & 51.1 & 22 & 48.9 & 45 & 100 \\
& 144 & 51.8 & 134 & 48.2 & 278 & 100 \\
\hline
\end{tabular}

Walaupun nyaris berimbang antara yang menilai baik dengan tidak baik, tetapi $51,8 \%$ responden menyatakan kinerja lingkungan penelitian kesehatan dalam kontribusinya bagi sistem penelitian kesehatan nasional secara keseluruhan masih belum baik. Peneliti $(54,3 \%)$ dan pengguna hasil litkes $(51,1 \%)$ cenderung menilai belum baik. Sebaliknya menurut 55\% kelompok pembuat kebijakan kinerja lingkungan penelitian kesehatan sudah baik.

\subsection{Penilaian Kinerja Fungsi Stewardship}

Dimensi ini didasarkan penghitungan skor kinerja menurut 5 komponen terpilih dari 13 komponen yang diidentifikasi oleh WHO. Ketigabelas komponen tersebut adalah : (1) pandangan; (2) prioritas; (3) etika; (4) evaluasi; (5) pendanaan; (6) alokasi; (7) manusia; (8) fisik; (9) penelitian : menghasilkan hasil penelitian yang valid secara ilmiah; (10) kebijakan; (11) praktek; (12) publik; (13) aplikasi. Sedangkan 5 komponen terpilih untuk menilai fungsi stewardship adalah : (1) pandangan; (2) etika; (3) evaluasi; (4) alokasi; (5) prioritas (Lihat Tabel 2).

Tabel 2. Kinerja Dimensi Pandangan Sistim pada Penelitian Kesehatan Menurut Kelompok Responden

\begin{tabular}{llllllll}
\hline \multirow{2}{*}{$\begin{array}{l}\text { Kelompok } \\
\text { Responden }\end{array}$} & \multicolumn{4}{c}{ Kategori kinerja } & & \\
\cline { 2 - 6 } & \multicolumn{2}{c}{ Tidak baik } & \multicolumn{2}{c}{ Baik } & & \multicolumn{2}{c}{ Total } \\
& N & $\%$ & N & $\%$ & N & $\%$ \\
\hline Peneliti & 77 & 44.5 & 96 & 55.5 & 173 & 100 \\
Pembuat kebijakan & 19 & 31.7 & 41 & 68.3 & 60 & 100 \\
Pengguna hasil litkes & 14 & 31.1 & 31 & 68.9 & 45 & 100 \\
& 110 & 39.6 & 168 & 60.4 & 278 & 100 \\
\hline
\end{tabular}

Penilaian dimensi pandangan sistem pada penelitian kesehatan menunjukkan hasil yang berbeda dari dimensi sebelumnya. Sekitar $60 \%$ responden pada masing-masing kelompok menilai kinerja pada dimensi ini sudah baik. Tetapi peneliti menilai kinerja fungsi ini lebih rendah dibanding penilaian kelompok lainnya. Hasil studi serupa di Laos menyebutkan responden berpendapat kinerja dimensi ini adalah sudah cukup baik.

\subsection{Fungsi Producing And Using Research}

Berbeda dengan pengukuran fungsi-fungsi sebelumnya, 
Tabel 3 Kinerja Fungsi Pembuatan dan Penggunaan Penelitian Kesehatan Menurut Kelompok Responden

\begin{tabular}{|c|c|c|c|c|c|c|c|c|c|}
\hline \multirow[t]{2}{*}{ Dimensi penilaian } & \multirow[t]{2}{*}{ Nilai Kinerja } & \multicolumn{2}{|c|}{ Peneliti } & \multicolumn{2}{|c|}{$\begin{array}{l}\text { Pembuat } \\
\text { Kebijakan }\end{array}$} & \multicolumn{2}{|c|}{$\begin{array}{l}\text { Pengguna } \\
\text { Hasil Litkes }\end{array}$} & \multicolumn{2}{|c|}{$\begin{array}{l}\text { Seluruh } \\
\text { Responden }\end{array}$} \\
\hline & & $\mathbf{N}$ & $\%$ & $\mathbf{N}$ & $\%$ & $\mathbf{N}$ & $\%$ & $\mathbf{N}$ & $\%$ \\
\hline \multirow{2}{*}{ Pembuatan litkes } & Baik & 119 & 68.8 & 16 & 26.7 & 11 & 24.4 & 146 & 52.5 \\
\hline & Tidak baik & 54 & 31.2 & 44 & 73.3 & 34 & 75.6 & 132 & 47.2 \\
\hline \multirow[t]{2}{*}{ Penggunaan hasil litkes } & Baik & 51 & 29.5 & 36 & 60 & 14 & 31.1 & 101 & 36.3 \\
\hline & Tidak baik & 122 & 70.5 & 24 & 40 & 31 & 68.9 & 177 & 63.7 \\
\hline \multirow[t]{2}{*}{ Akses literatur } & Baik & 87 & 50.3 & 23 & 18.3 & 16 & 35.6 & 126 & 45.3 \\
\hline & Tidak baik & 86 & 49.7 & 37 & 61.7 & 29 & 64.4 & 152 & 54.7 \\
\hline \multirow[t]{2}{*}{ Akses media } & Baik & 83 & 48 & 28 & 46.7 & 22 & 48.9 & 133 & 47.8 \\
\hline & Tidak baik & 90 & 52 & 32 & 53.3 & 23 & 51.1 & 145 & 52.2 \\
\hline \multirow[t]{2}{*}{ Seluruh dimensi } & Baik & 90 & 52 & 21 & 35 & 13 & 28.9 & 162 & 58.3 \\
\hline & Tidak baik & 83 & 48 & 39 & 65 & 32 & 71.1 & 116 & 41.7 \\
\hline
\end{tabular}

pada fungsi ini penilaian kinerja tidak berdasarkan pendapat responden tetapi berdasarkan aktifitas dan pengalaman nyata responden dalam melakukan penelitian, dari proses merencanakan sampai memanfaatkan hasil penelitian kesehatan. Aktifitas tersebut meliputi mencari literatur ilmiah, membuat proposal, menilai proposal, mengevaluasi, melakukan penilaian etik penelitian, melakukan kajian, menulis publikasi, menghadiri pertemuan ilmiah, mengakses jurnal/publikasi ilmiah, akses internet, dan mendaftarkan paten hasil penelitian. Penilaian kinerja fungsi ini terdiri atas 4 dimensi penilaian yaitu : (1) pembuatan (produksi) penelitian kesehatan; (2) penggunaan hasil penelitian kesehatan; (3) akses literatur ilmiah; dan (4) akses media (lihat tabel 3).

Secara umum fungsi pembuatan dan penggunaan litkes oleh peneliti $(52 \%)$, pembuat kebijakan $(35 \%)$, dan penguna hasil litkes (28.9\%) dinilai sudah baik hasil ini menunjukkan bahwa peneliti cenderung menilai baik kinerja sistem ini dibandingkan dengan kelompok pembuat kebijakan dan pengguna hasil litkes. Dari keempat dimensi penilaian pada fungsi ini, kinerja baik hanya dinilai pada dimensi produksi/pembuatan litkes, sementara dimensi lainnya dinilai belum baik. Hasil ini menunjukkan bahwa aktifitas pembuatan penelitian sudah baik, tetapi aktifitas pemanfaatan hasil, diseminasi, akses media dan akses literatur ilmiah merupakan hal-hal penting yang perlu ditingkatkan. Kondisi ini nampaknya lebih dirasakan oleh peneliti dibandingkan kelompok lainnya yang tidak langsung menangani 'produksi' suatu penelitian. Hal yang perlu dicermati, pada seluruh dimensi penilaian, kelompok pengguna hasil litkes cenderung menilai tidak baik.

\subsection{Penilaian Kinerja Seluruh Fungsi Sistem}

Kinerja seluruh dimensi adalah rata-rata dari penjumlahan skor kinerja pada ke 6 dimensi tersebut di atas. Tabel tersebut menunjukkan bahwa penilaian kinerja hampir berimbang. Sebanyak 49,6\% responden menilai secara umum kinerja fungsi sistem litkes nasional sudah baik, sebaliknya 50,4\% menyatakan kinerja belum baik. Peneliti dan pembuat kebijakan cenderung menilai kinerja fungsi sistem litkes belum baik, sedangkan pengguna hasil litkes berpendapat sebaliknya. Secara langsung hasil ini memperlihatkan bahwa fungsi sitem litkes di Indonesia belum optimal untuk mendukung terciptanya lingkungan dan sistem yang kondusif bagi produksi dan pemanfaatan hasilhasil litkes.

Tabel 4. Kinerja Seluruh Fungsi Menurut Kelompok Responden

\begin{tabular}{|c|c|c|c|c|c|c|}
\hline \multirow{3}{*}{$\begin{array}{l}\text { Kelompok } \\
\text { Responden }\end{array}$} & \multicolumn{4}{|c|}{ Kategori kinerja } & & \\
\hline & \multicolumn{2}{|c|}{ Tidak baik } & \multicolumn{2}{|c|}{ Baik } & \multicolumn{2}{|c|}{ Total } \\
\hline & $\mathbf{N}$ & $\%$ & $\mathbf{N}$ & $\%$ & $\mathbf{N}$ & $\%$ \\
\hline Peneliti & 99 & 57.2 & 74 & 42.8 & 173 & 100 \\
\hline Pembuat kebijakan & 31 & 51.7 & 29 & 48.3 & 60 & 100 \\
\hline Pengguna hasil litkes & 22 & 48.9 & 23 & 51.1 & 45 & 100 \\
\hline & 140 & 50.4 & 138 & 49.6 & 278 & 100 \\
\hline
\end{tabular}

\section{Analisis kualitatif}

Analisis dari beberapa jawaban responden terhadap pertanyaan terbuka mengidentifikasi beberapa isu penting terkait dengan fungsi sistem litkes nasional. Responden pada ketiga kelompok menyatakan dari 10 area, disebutkan 5 (lima) area yang paling kontributif dan prioritas dalam lingkungan litkes yaitu : networking, fasilitas, pendanaan, relevansi, kolaborasi dan komunikasi. Sedangkan untuk 13 komponen sistem litkes, dipilih 5 komponen yang dinilai paling kontributif dan prioritas untuk penguatan adalah visi, sdm, etika penelitian kesehatan, pendanaan dan alokasi.

Penetapan agenda riset kesehatan adalah hal penting yang perlu dipertimbangkan dengan baik karena akan terkait dengan pemanfaatan hasil litkes. Responden pada ketiga kelompok mengidentifikasi masalah kesehatan masa depan atau yang diperkirakan dan masalah kesehatan persisten atau yang bertahan lama menjadi 2 pilihan utama sebagai dasar penetapan prioritas agenda litkes di Indonesia. Sedangkan pilihan utama yang ketiga menurut pembuat kebijakan dan pengguna hasil litkes adalah kebijakan pengobatan di masyarakat rentan, sedangkan menurut 
peneliti adalah dasar pengetahuan yang baru tentang kondisi penyakit dan faktor risiko. Ketersediaan anggaran ternyata dinilai responden bukan sebagai alasan utama penetapan prioritas litkes, walau kondisi riil di Indonesia menunjukkan sebaliknya.

Mengenai kolaborasi dalam sistem litkes nasional, diketahui bahwa kegiatan kolaborasi sudah berjalan cukup baik dan variatif diantara para stakeholder dalam sistem penelitian kesehatan. Peningkatan dan pengembangan kerjasama akan menjadi kekuatan penggerak untuk mendapatkan akses sumber daya dan menjangkau sasaran (masyarakat) yang lebih luas.

Lebih lanjut, responden juga dimintakan pendapatnya mengenai instrumen dalam penelitian ini. Hampir seluruh responden menyatakan bahwa kuesioner tersebut sulit dipahami, membutuhkan waktu yang lama, tidak sederhana, dan pertanyaan tidak general bisa dijawab oleh seluruh kelompok responden karena banyak yang kelihatannya ditujukan khusus untuk peneliti. Oleh sebab itu, untuk kebutuhan survey serupa di masa mendatang, instrumen ini perlu diperbaiki.

\section{Pembahasan}

Karakteristik responden penting diketahui sebagai gambaran ataupun latar belakang yang mempengaruhi penilaian persepsi responden terhadap kinerja sistem penelitian kesehatan. Dari hasil penelitian ini diketahui bahwa pemilihan responden yang diwawancarai sudah cukup baik, karena distribusi jenis kelamin, umur, pengalaman bekerja, tingkat pendidikan, dan tingkat penghasilan menunjukkan variasi yang baik, sehingga responden dinilai cukup baik untuk memberikan penilaian berdasarkan persepsi dan pengalamannya.

Temuan menarik dari gambaran karakteristik ini adalah pada potensi sdm yang cukup baik (qualified) dari segi tingkat pendidikan. Sdm dalam sistem penelitian kesehatan memegang peranan sangat penting sebagai sumber daya utama berjalannya sistem tersebut. ${ }^{7}$ Peningkatan kapasitas sistem litbangkes perlu dilakukan secepatnya untuk sustainability sumber daya potensial yang ada. Berat dan besarnya tekanan melakukan penelitian kesehatan berkualitas dalam kondisi keterbatasan fasilitas, pendanaan, sistem bayaran/gaji dan tunjangan yang tidak memuaskan, dsb dapat mengakibatkan perpindahan sdm potensial dari sektor publik ke sektor swasta yang lebih menjanjikan keuntungan finansial.

Meskipun dinilai sangat penting, sdm yang profesional dalam sistem penelitian kesehatan tidak akan berarti tanpa dukungan fasilitas dan dana yang memadai. Lingkungan yang kondusif bagi peneliti untuk melahirkan temuantemuan yang inovatif dan aplikatif dalam menunjang pembangunan kesehatan sangat penting diupayakan. Temuan studi ini menyebutkan 2 hal prioritas yang perlu diperbaiki dalam fungsi creating and sustaining resources adalah dana dan fasilitas. Persentase biaya penelitian kesehatan terhadap biaya kesehatan nasional pada periode 1997 - 2002 adalah berkisar 0,14-0,2\% atau terhadap GDP berkisar 0,0036 $\%-0,0045 \% .^{6,8}$ Fasilitas yang minim juga banyak disampaikan dalam berbagai diskusi. ${ }^{9}$ Ditengah berbagai keterbatasan tersebut, maka yang perlu ditingkatkan adalah kompetensi peneliti untuk mendapatkan research grants dan peningkatan kerjasama dan kemitraan antar institusi penelitian, terutama dalam kaitannya dengan facilities sharing.

Dari ke 6 dimensi penilaian, fungsi yang dinilai baik oleh seluruh responden adalah stewardship. Fungsi ini mengisyaratkan tentang pentingnya komitmen pemerintah dan kepemimpinan yang baik dalam manajemen penelitian yang efektif atau yang diidentifikasi sebagai good scientific leadership. Kepemimpinan yang baik akan mampu mengidentifikasi prioritas penelitian kesehatan sesuai permasalahan prioritas kesehatan nasional yang benar-benar mampu memberikan kontribusi maksimal bagi peningkatan kesehatan masyarakat menuju tercapainya pemeratan, paradigma inilah yang dikenal dengan konsep "knowledge for better life'. Paradigma konsep kepemimpinan tersebut perlu dirubah bukan lagi menekankan pada fungsi 'directing' tetapi 'stewardship' dimana mengandung nilai-nilai penggerakan/motivating, endorsement, encouragement, seluruh stakeholder terkait.

Dari segi kelembagaan, badan penelitian kesehatan, Depkes RI telah ditetapkan sebagai focal point kegiatan litbangkes nasional. Focal point dalam kegiatan penelitian kesehatan pada level nasional akan sangat bermanfaat untuk merumuskan kebijakan makro, terutama dalam identifikasi visi dan prioritas nasional penelitian kesehatan. Lebih lanjut perlu dibangun kemitraan dengan komisi independen di tingkat nasional seperti komisi nasional etik litkes, komisi nasional jarlitbangkes, dan dewan riset nasional (drn). Pada kenyataannya badan litbangkes kesulitan mengerjakannya semuanya 'sendiri' dalam melakukan koordinasi, asistensi dan pembinaan eksternal, tetapi di sisi lain masih mengalami kendala dalam melakukan pembenahan dan penguatan internal kelembagaannya. Contoh pengalaman di Philipina dalam mereformasi sistem penelitian kesehatannya adalah dimulai dengan pembentukan komisi nasional litkes. Penguatan kapasitas kelembagaan badan litbangkes secara langsung dapat berdampak bagi peningkatan peran dan fungsi sistem litkes nasional.

Berbagai payung kebijakan sudah ditetapkan, seperti misalnya sk menkes no. 1179a/1995 tentang kebijakan nasional litbangkes, ${ }^{10}$ pp no. 39/1995 tentang litbangkes, ${ }^{11}$ UU no. 18/2002 tentang sistem nasional penelitian, ${ }^{12}$ pengembangan dan penerapan ilmu pengetahuan dan teknologi yang diikuti dengan pp no. 20 tahun 2005 tentang alih teknologi kekayaan intelektual serta hasil penelitian dan pengembangan oleh perguruan tinggi dan lembaga penelitian dan pengembangan, dan sebagainya. ${ }^{13}$ Secara makro 
dukungan kelembagaan dan kebijakan nasional penelitian termasuk di bidang kesehatan terkait dengan fungsi stewardship sudah cukup baik. Kendala besar yang dihadapi adalah pada kapasitas kelembagaan, minimnya dana dan fasilitas, pemberdayaan sdm penelitian, serta mekanisme monitoring dan evaluasi kinerja sistem penelitian kesehatan, sehingga sustainability atau keberlanjutan program ini masih sangat tergantung dengan komitmen pemerintah. Lebih lanjut pengembangan fungsi stewardship sangat membutuhkan kerjasama dan kemitraan antar seluruh aktor dalam tata pemerintahan atau dengan kata lain, komitmen perbaikan dapat dicapai melalui penyelanggaraan negara yang bersih dan bertanggung jawab melalui aplikasi prinsipprinsip good goverment.

Fungsi berikutnya adalah producing and using research. Dari penilaian terhadap 4 dimensi dalam fungsi ini menunjukkan dimensi produksi litkes yang dinilai cukup baik. Data dari hasil survey alur sumber daya penelitian kesehatan I dan II menyebutkan bahwa pada tahun 1997 - 1999 sejumlah 4468 penelitian yang dikerjakan oleh 130 institusi di 18 provinsi; dan tahun 2000 - 2002 sejumlah 2381 penelitian yang dikerjakan oleh 128 institusi di 17 provinsi. 6,8 Sebagai perbandingan survey yang sama di Philipina menyebutkan pada tahun 1997 - 1998 penelitian kesehatan di negara tersebut berjumlah 866 penelitian kesehatan ${ }^{14}$ dan survey di Mesir menyebutkan angka yang lebih fantastis yaitu 10702 penelitian selama 1999 - 2001. ${ }^{15}$ Aktifitas 'produksi' penelitian kesehatan di Indonesia sudah cukup baik.

Banyaknya jumlah penelitian kesehatan menunjukkan bahwa dari segi supply nampaknya Indonesia sangat potensial untuk mengembangkan hasil-hasil penelitiannya dalam berbagai kajian tindak lanjut untuk merumuskan program, model, teknologi dan kebijakan baru. Sayangnya masih banyak hasil penelitian yang belum mampu dimanfaatkan dengan maksimal untuk perencanaan program dan perumusan kebijakan kesehatan baik pada level nasional maupun di daerah. Hasil rtd survey alur sumber daya litbangkes, mengungkapkan keluhan pelaksana program (kelompok pembuat kebijakan) bahwa hasil-hasil penelitian tidak tersosialisasi dengan baik dan juga hasilnya kurang dapat mendukung program karena cenderung tidak menghasilkan sesuatu yang aplikatif untuk program intervensi baru. ${ }^{6}$ Selain itu juga disampaikan bahwa penelitian yang dilakukan banyak yang tidak sesuai atau belum mendukung kebutuhan program. Sementara di pihak peneliti, menyatakan bahwa walaupun publikasi dan advokasi sudah mereka lakukan, nampaknya belum mendapat perhatian yang layak dari pihak pembuat kebijakan untuk memanfaatkan hasil penelitian mereka.

Temuan tersebut mengisyaratkan perlunya merevisi kembali prioritas dan agenda nasional penelitian kesehatan untuk menjawab kebutuhan pihak pelaksana program dan kapasitas sumber daya penelitian. Hal yang sama juga terjadi di banyak negara di seluruh dunia. Kesenjangan antara produser penelitian (peneliti) dan user (pembuat kebijakan) salah satunya disebabkan karena ketidakmampuan melakukan sintesis hasil-hasil penelitian kesehatan menjadi temuan baru bagi intervensi program dan meningkatkan kinerja sistem kesehatan. ${ }^{5}$ WHO menyebutkan bahwa pendekatan komunikasi hasil penelitian kesehatan kepada masyarakat luas akan berdampak dalam meningkatkan kepedulian publik akan pentingnya penelitian kesehatan dalam meningkatkan kemajuan iptek kesehatan. Lebih lanjut kepedulian ini akan mendorong partisipasi ilmiah, yang akhirnya berdampak pada advokasi dan promosi pemanfaatan hasil litkes untuk pembangunan kesehatan. ${ }^{5}$

Dalam kaitannya dengan proses pembuatan dan penggunaan hasil penelitian kesehatan, tentunya tidak terlepas dari akses peneliti terhadap teknologi informasi dan komunikasi. Dari berbagai diskusi juga disampaikan bahwa selain faktor motivasi peneliti, ada juga yang menyatakan bahwa peneliti mengalami kesulitan mencari literatur ilmiah untuk jurnal-jurnal internasional tertentu yang tidak free akses dan cukup mahal. Kondisi ini banyak dialami oleh penelitipeneliti di negara miskin dan berkembang. ${ }^{5}$

Kecenderungan perkembangan informasi saat ini adalah meningkatnya pemanfaatan teknologi internet untuk publikasi hasil penelitian dan penelusuran literatur ilmiah. Temuan studi ini menyebutkan bahwa masih banyak responden yang belum optimal memanfaatkan teknologi internet untuk menunjang kegiatan penelitian dan publikasi hasilnya, padahal dukungan fasilitas di tempat kerja sudah cukup baik. Tetapi sayangnya akses internet belum merata mudah didapat di daerah. Internet sendiri masih menjadi suatu teknologi yang mahal di Indonesia, sehingga pengadaan sambungan internet pribadi di rumah-rumah hanya dapat dinikmati oleh golongan ekonomi atas. Kondisi ini secara langsung akan menjadi hambatan bagi penyebarluasan hasil penelitian berbasis internet. Sedangkan publikasi hasil penelitian melalui jurnal ilmiah (media cetak) dalam negeri, masih beredar di kalangan terbatas saja.

Suatu alternatif solusi yang ditawarkan dan sebenarnya kegiatan ini sudah berkembang sejak tahun 2001 dengan dibentuknya jaringan perpustakaan kesehatan/kedokteran di Indonesia, yaitu antar perpustakaan di universitas negeri dan swasta yang memiliki fk/fkg/fkm/farmasi dan badan litbangkes ditunjuk sebagai focal point. Jaringan ini dibentuk dengan memanfaatkan kerjasama dalam penelusuran bahan pustaka untuk menunjang kegiatan penelitian kesehatan. Melalui pemanfaatan jaringan ini, para peneliti dari berbagai daerah dapat mencari berbagai bahan pustaka dengan lebih mudah dan murah, selain itu perpustakaan juga dapat mengefisienkan anggarannya yang terbatas untuk pemilihan pengadaan bahan pustaka yang lebih prioritas. Fasilitas ini juga dipermudah dengan on line katalog perpustakaan-perpustakaan yang masuk dalam jaringan tersebut. Selain itu juga dikembangkan teknologi digital library (digilib) dimana seorang peneliti yang $\log$ in dalam website digilib dapat 
langsung mengirimkan berbagai tulisan ilmiahnya untuk kemudian dapat diakses oleh masyarakat luas melalui internet. Sayangnya keberadaan jaringan ini masih belum tersosialisasi dengan baik. Sekali lagi, fungsi stewardship akan sangat berpengaruh besar dalam fasilitator dan mediator jaringan.

\section{Kesimpulan}

Secara keseluruhan kinerja fungsi sistem litkes nasional belum berfungsi optimal. Penilaian kinerja baik adalah pada fungsi stewardship dan producing research, sebaliknya, diperlukan peningkatan kinerja fungsi sistem adalah pada fungsi creating and sustaining resources dan fungsi using research, termasuk pada akses literatur ilmiah dan akses media.

Perbedaan penilaian antar kelompok responden menunjukkan pada kelompok peneliti dan pengguna hasil litkes; kinerja sistem yang sudah baik ada pada fungsi stewardship dan producing and using health research. Sebaliknya, fungsi creating and sustaining resources adalah belum baik, tetapi menurut pembuat kebijakan, ketiga fungsi sistem sudah cukup baik.

\section{Saran}

Upaya peningkatan kinerja sistem dapat difokuskan pada :

- Fungsi creating and sustaining resources: aspek dana dan fasilitas. Perbaikan dapat dilakukan dengan peningkatan kompetensi untuk mendapat research grants; kebijakan pembiayaan litkes secara bertahap 2\% dari APBN kesehatan; dan aktivasi jaritbangkes di pusat dan daerah.

- Fungsi stewardship: intensifikasi dan penguatan komisi nasional independen di bidang litkes, termasuk kemitraan antara drn dan badan litbangkes; revisi agenda riset nasional dengan melibatkan stakeholders terkait. Penetapan prioritas agenda riset dapat mempertimbangkan temuan studi ini yaitu pada masalah kesehatan masa depan dan masalah kesehatan persisten.

- Fungsi producing and using health research : perbaikan difokuskan pada 3 elemen sistem yaitu pada peningkatan pemanfaatan dan promosi hasil penelitian kesehatan, akses literatur ilmiah, dan akses media dalam hal ini optimalisasi pemanfaatan internet untuk kepentingan penelusuran literatur dan publikasi ilmiah. Aspek khusus lainnya yang juga perlu menjadi perhatian adalah peningkatan untuk mengajukan paten atau haki atas suatu hasil penelitian kesehatan yang potensial.

- Selain itu beberapa saran perbaikan untuk instrumen survei analisa sistem penelitian kesehatan nasional adalah: penyederhanaan kuesioner agar lebih mudah dipahami responden; untuk beberapa hal yang berbeda jangan disampaikan dalam satu pernyataan; modul perlu ditambahkan mengenai fungsi sistem financing; survey serupa dapat dikembangkan untuk kota-kota lain di Indonesia dengan menggunakan instrumen yang telah diperbaiki; dan perlu ada panduan analisis data survey. Untuk mendapatkan hasil yang lebih komprehensif, analisis sebaiknya juga dilakukan bersama komponen hrsa study lainnya (survei institusi dan survei media).

\section{Daftar Pustaka}

1. World health organization. National health research systems. Geneva; januari 2002.

2. World health organization. World report on knowledge for better health: streghtening health systems. Geneva; november 2004.

3. World health organization. WHO health research sistem analysis initiative : brief overview. Geneva; september 2003.

4. Departemen Kesehatan RI. Sistem kesehatan nasional. Jakarta, 2004.

5. World health organization. Materials kit of $W H O$ capacity strengthening workshop on health research sistem analyses sopporting in-depth country studies and regional analyses. New delhi; 19 - 21 oktober 2004.

6. Badan penelitian dan pengembangan kesehatan: laporan survey alur sumber daya litbangkes di indonesia tahun 2000 - 2002. Jakarta; 2004.

7. Pang $\mathrm{t}$, et al.. Knowledge for better health - a conceptual framework and foundation for health research system. WHO; 2003.

8. Badan penelitian dan pengembangan kesehatan: laporan survey alur sumber daya litbangkes di indonesia tahun 1997 - 1999. Jakarta; 2001.

9. Badan Penelitian dan Pengembangan Kesehatan Depkes RI. Prosiding lokakarya nasional litbangkes, Ciloto, 9-11 Juli 2003. Jakarta; Oktober 2003.

10. Keputusan Menteri Kesehatan No. 1179A/1999 tentang kebijakan nasional penelitian dan pengembangan kesehatan (jaknas litbangkes). Depkes RI Jakarta, 1999.

11. Peraturan Pemerintah No. 39 Tahun 1995 tentang penelitian dan pengembangan Kesehatan. Jakarta, 1995.

12. Undang-undang RI No. 18 tahun 2002 tentang sistem nasional penelitian, pengembangan dan penerapan ilmu pengetahuan dan teknologi. Kementerian Riset dan Teknologi. Jakarta, 2002.

13. Peraturan Pemerintah No. 20 tahun 2005 tentang Alih teknologi kekayaan intelektual serta hasil penelitian dan pengembangan oleh perguruan tinggi dan lembaga penelitian dan pengembangan. Jakarta, 2005.

14. Cohred. Health research for development: the continuing challenge, a discussion paper, international conference on health research for development, Bangkok, Thailand, 10-13 October 2000 (Conference paper).

15. World health organization - regional office for the eastern mediteranian. A study of national health research systems in selected east mediteranian countries. The WHO em region, egypt; 2004. 